\title{
Современное пособие по методам экологических исследований
}

\author{
(Каверина Н. В., Прожсорина Т. И., Иванова Е. Ю., Клевцова М. А., Куролап С. А., \\ Клепиков О. В., Муравьев А. Г., Никольская А. Н., Синегубова В. В. Методы \\ экологических исследований: учебное пособие для вузов [гриф ФУМО «Науки о \\ Земле»]. Воронеж, Издательство «Научная книга», 2019. 355 с.)
}

\author{
О.П. Негробов $\bowtie$ \\ Воронежский государственньй университет, Российская Федерация \\ (394018, г. Воронеж, Университетская пл., 1)
}

\begin{abstract}
Для цитирования: Негробов О. П. Современное пособие по методам экологических исследований // Вестник Воронежского государственного университета. Серия География. Геоэкология, 2020, № 3, c. 101-103. DOI: https://doi.org/10.17308/geo.2020.3/3031
\end{abstract}

Опубликованное новое учебное пособие «Методы экологических исследований» Н. В. Кавериной с соавторами, отмеченное грифом ФУМО «Науки о Земле», является очень своевременным и актуальным изданием, полезным в преподавании экологии и смежных дисциплин студентам экологогеографических направлений вузов.

Современная экология относится к комплексным наукам, включающим основы многих естественных и ряда гуманитарных наук и имеющих сложившиеся в течение многих лет объекты исследования и методы их изучения. Поэтому авторам учебного пособия предстояло провести анализ и выбрать наиболее адекватные методы из многих классических дисциплин.

Удачно выбранный практико-ориентированный подход нацелен на развитие технологического подхода к решению экологических задач, а также развитие самостоятельных навыков обучающегося по овладению современными методами, технологиями и приборной базой для решения профессиональных ситуаций в области экологии и охраны окружающей среды.

Методологическая основа издания базируется на современных принципах рационального природопользования с учетом понимания того, что выбор стратегии и тактики рационального природопользования, а также охраны окружающей среды невозможен без строгой научной оценки реально- го состояния среды обитания. При этом особую роль играет контроль воздуха, воды и почвы как природных компонентов, подвергающихся непосредственному загрязнению. В настоящее время информация о состоянии отдельных компонентов окружающей среды собирается в основном путем отбора проб и их последующего анализа в лабораторных условиях. Реально разработаны и применяются дистанционные и автоматические методы средства контроля, но метод отбора проб продолжает играть существенную роль, так как не все характеристики объектов окружающей среды могут быть измерены дистанционно; кроме того, отобранные пробы могут быть использованы в качестве контрольных замеров.

Учебное пособие охватывает лабораторные практикумы по циклам следующих дисциплин эколого-географического профиля: уровень - бакалавриата: «Общая экология», «Геохимия окружающей среды», «Экологический мониторинг», «Биоиндикация», «Аналитические методы контроля окружающей среды», «Токсикология и биотестирование», «Экология человека»; уровень - магистратуры: «Эколого-геохимический мониторинг», «Социально-гигиенический мониторинг».

Пособие состоит из отдельных разделов. В первой главе «Современные методы эколого-аналитических исследований» рассматриваются методика проведения лабораторных работ, принци-

(C) Негробов О.П., 2020

凶 Негробов Олег Павлович, e-mail: negrobov@ list.ru

Контент доступен под лицензией Creative Commons Attribution 4.0 License. 
пы эколого-аналитических исследований, портативные лаборатории анализа, тест-комплекты для анализа воды и почвы, а также настольная почвенная лаборатория НПЛ.

Вторая глава посвящена эколого-химическим методам исследований окружающей среды и посвящена описанию методов отбора проб атмосферного воздуха и промышленных выбросов, отбора проб воды и почвы, измерений концентраций загрязняющих веществ и математической обработки данных.

Приводится подробное описание 51 лабораторной работы, которые раскрывают методики определения отдельных веществ в природных экосистемах, в том числе расчет доверительного интервала метода, расчет чувствительности и пределов обнаружения фотометрического метода, расчет навесок для приготовления почвенных вытяжек, построение калибровочного графика по методу наименьших квадратов, гравиметрическое определение запыленности воздуха, определение диоксида серы в воздухе турбодиметрическим методом, определение оксидов азота в атмосфере фотоколориметрическим методом, очистка воздуха от диоксида углерода методом абсорбции, экспрессное определение оксида углерода на рабочем месте сварщика, титриметрическое определение кальция в природных водах, определение тяжелых металлов в почвах и ряд других методик лабораторно-инструментальных исследований.

Третья глава связана с методами биотестирования и биоиндикации, в том числе качественной реакцией на определения наличия ДДТ в пищевых продуктах, биотестированием токсичности воды с использованием Ряски малой (Lemna minor L.), определением общего микробного числа в воде и почве, определением нитратов в различных овощных культурах в зависимости от вида, сорта, органа, ткани и рядом других методик.

Четвертая глава посвящена статистическим методам оценки экологического риска для здоровья населения, в которой рассматриваются алгоритмы расчета экологических рисков для здоровья населения с использованием когортного метода, теоретические основы методологии оценки риска и практические примеры расчета рисков вследствие загрязнения атмосферного воздуха и питьевой воды. Предлагается шесть лабораторных работ с примерами расчетов экологических рисков для здоровья населения.

В целом пособие включает 86 лабораторных работ. Предложенные лабораторные работы помимо учебного процесса будут полезны в научно-исследовательской деятельности сотрудников, аспирантов и студентов естественно-географических специальностей в области экогеохимии, биоиндикации, биотестирования и мониторинга окружающей среды, экологии человека и оценки риска для здоровья населения.

Большинство предлагаемых лабораторных работ базируется на апробированных методах, заимствованных из государственных стандартов, ведомственных нормативно-правовых документов, а также унифицированных методик, ссылки на которые приведены в списках рекомендуемой литературы по соответствующим разделам учебного пособия. Большинство работ и описанные методические подходы имеют оригинальный авторский характер.

Учебное пособие предназначено для студентов высших учебных заведений, обучающихся по направлению «Экология и природопользование» (05.03.06 - уровень бакалавриата и 05.04.06 - уровень магистратуры).

Следует отметить, что пособие издано совместно с научно-производственным объединением Закрытым акционерным обществом «Крисмас+» (г. Санкт-Петербург), которое является ведущим предприятием отечественной индустрии по производству и оснащению учебных заведений и профессиональных служб лабораторным оборудованием для экологических исследований.

Учебное пособие значительно отличается от подобных изданий по методам исследования в экологии своей комплексностью, информативностью и к настоящему времени является лучшим практическим пособием по экологии среди современной литературы.

Конфликт интересов: Автор декларирует отсутствие явных и потенциальных конфликтов интересов, связанных с публикацией настоящей статьи.

Поступила в редакциию 11.06.2020 Принята к публикации 26.07.2020 


\title{
A Modern Guide to Environmental Research Methods
}

(Kaverina N. V., Prozhorina T.I., Ivanova E. Yu., Klevtsova M.A., Kurolap S.A., Klepikov O. V., Muravyov A. G.. Nikolskaya A. N., Sinegubova V. V. Methods of Environmental Research: a study guide for universities [stamp FUMO "Earth Sciences"]. Voronezh, Publ. house "Scientific book", 2019. 355 p.)

\author{
O.P. Negrobov $\bowtie$ \\ Voronezh State University, Russian Federation \\ (394018 Voronezh, Universitetskaya sq., 1)
}

For citation: Negrobov O.P. A modern guide to environmental research methods. Vestnik Voronezskogo gosudarstvennogo universiteta. Geografia geoekologia, 2020, No. 3, pp. 100-103. (In Russ.) DOI: https://doi.org/10.17308/geo.2020.3/3031

Conflict of interests: The author declares no information of obvious and potential conflicts of interest related to the publication of this article.

Received: 11.06 .2020

Accepted: 26.07 .2020

Негробов Олег Павлович

доктор биологических наук, профессор медико-биологического факультета Воронежского государственного университета, г. Воронеж, Российская Федерация, ORCID: https://orcid.ogr/0000-0001-8846-5168, e-mail: negrobov@list.ru
Oleg P. Negrobov

Dr. (Biol.) Sci., Professor of the Faculty of Medicine and Biology, Voronezh State University, Voronezh, Russian Federation, ORCID: https://orcid.ogr/0000-0001-8846-5168, e-mail: negrobov@list.ru 